\title{
BIMBINGAN DAN PENYULUHAN GURU-GURU PAUD DI PAUD EL SHADDAY, KEC. MEDAN DELI, KOTA MEDAN, PROV. SUMUT
}

\author{
Angelia Maharani Purba \\ Politeknik Negeri Medan, Medan, Indonesia \\ e-mail: angeliapurba@polmed.ac.id \\ Arlina Pratiwi Purba \\ Politeknik Negeri Medan, Medan, Indonesia \\ e-mail: arlinapurba@polmed.ac.id \\ Miduk Purba \\ Politeknik Negeri Medan, Medan, Indonesia \\ e-mail: midukpurba@polmed.ac.id \\ Eva Malina Simatupang \\ Politeknik Negeri Medan, Medan, Indonesia \\ e-mail: malinasimatupang@polmed.ac.id
}

\begin{abstract}
Pendidikan Anak Usia Dini (PAUD) ditujukan bagi anak sejak lahir hingga usia 6 tahun, yang diatur dalam UUD No. 20 Tahun 2003. Pentingnya Pendidikan anak sejak usia dini sudah disadari oleh masyarakat yang terlihat dari berkembang pesatnya lembaga pendidikan bagi anak-anak usia balita seperti kelompok bermain, taman kanak-kanak dan sekolah dasar bauk yang dikelola yayasan maupun berbagai lembaga keagamaan salah satunya adalah PAUD EI Shadday. Pendidikan PAUD sendiri tidak hanya berfokus pada pemberian stimulasi pengayaan pengetahuan anak tetapi lebih diarahkan kepada pemberian potensi dan daya kreatifitas serta pembentukan suikap mental dan kepribadian anak. Hal ini akan menjadi dasar untuk pembentukan karakter dan kepribadian anak hingga dewasa. Pengabdian ini dilaksanakan di Paud El Shadday Kecamatan Medan Deli dan bertujuan untuk meningkatkan kreativitas mengajar guruguru PAUD. Kegiatan pengabdian yang telah dilaksanakan adalah bimbingan dan penyuluhan dari narasumber dibidang psikologi anak dan pemberian permainan edukatif. Hasil dari kegiatan ini adalah guru PAUD lebih memahami karakter anak didik, meningkatkan kreativitas guru melalui penambahan permainan edukatif anak dan pemanfaatan bahan-bahan yang ada disekitar dalam meningkatkan sensorik, motorik dan psikomotorik anak, serta bertambahnya rak besi buku sebagai tempat menyimpan buku pelajaran dan prakarya anak didik.
\end{abstract}

Keywords- Edukatif, Kognitif, Afektif, Psikomotorik, PAUD

\section{PENDAHULUAN}

$A$ nak dan permainan merupakan dua pengertian yang hampir tidak dapat dipisahkan satu sama lain. Berpikir mengenai anak selalu menimbulkan asosiasi mengenai bermain. Timbul pertanyaan apakah bermain betul-betul 
merupakan kesibukan khusus anak (F.J. Monks, dkk., 1989: 115). Menurut MJ. Langeveld (1979: 25) permainan adalah merupakan kesibukan yang paling hakikat dengan suatu dunia anak yang hidup aman.

Pendidikan anak usia dini tidak lepas dan bermain. Bermain dapat mengasah banyak aspek kecerdasan bagi anak. Hanya sayangnya, banyak orang tua kadang yang beranggapan bermain tidak memiliki banyak manfaatnya, bahkan tidak jarang orang tua komplain ketika mengetahui bahwa di sekolah anak-anak hanya bermain. Orang tua beranggapan anak mereka disekolahkan untuk diajarkan tentang membaca, menulis dan berhitung. Padahal sesungguhnya masa pra sekolah adalah masa bermain (Arri Handayani, 2009: 07).

Paud El Shadday berdiri pada tahun 2003 dengan memulai dari tempat penitipan anak dimana rentang usia anak yang dititipkan pada waktu itu adalah 2 bulan - 6 tahun. Kemudian tahun 2004, tempat penitipan anak diubah menjadi sekolah Paud. Latar belakang anak yang sekolah di Paud ini adalah anak buruh pabrik yang tinggal di sekitar daerah Jl. Platina, Medan. Paud El Shadday memiliki 3 orang guru dan 1 orang kepala sekolah yang berpendidikan Sarjana dari berbagai ilmu yang bukan berasal dari Pendidikan keguruan khusus anak Paud.

Saat ini Paud El-Shadday memiliki keterbatasan dalam beraktivitas di luar ruangan. Selain sarana yang tidak ada juga dikarenakan kondisi covid yang mengurangi aktivitas di luar ruangan, sehingga sangat diperlukan kreativitas guru untuk melatih sensorik, motorik dan psikomotorik anak didik melalui permainan edukatif yang dapat dilakukan di dalam ruangan. Selain itu keterbatasan tempat juga menjadi permasalahan yang dialami mitra.

Berdasarkan permasalahan dan kebutuhan yang dihadapi oleh mitra, maka kami sebagai tenaga pengajar di Politeknik Negeri Medan ingin membantu mitra dengan memberikan bimbingan dan penyuluhan kepada guru-guru Paud. Bimbingan dan Penyuluhan berupa metoda, cara menyampaikan, materi, dan bantuan bahan pelajaran. Bimbingan dan penyuluhan akan dibimbing langsung oleh narasumber yang ahli dibidangnya. Selain itu juga menyediakan alat peraga berupa permainan edukatif, serta memberikan rak penyimpanan buku pelajaran anak didik.

\section{METODE}

Berdasarkan Solusi dan target luaran yang diharapkan, maka metode pelaksanaan kerjasama kemitraan ini dilakukan dengan cara :

1. Memberikan bimbingan dan penyuluhan kepada Kepala Sekolah dan 3 orang guru oleh Narasumber seorang Pakar Psikolog Anak yaitu Pradita Permatasari Sibagariang, M.Ed, M.Psi secara online selama 2 hari dari tanggal 26 - 27 November 2021.

2. Memberikan alat permainan edukatif anak Paud sebanyak 11 buah, serta

3. Memberikan 1 buah rak buku besi untuk penyimpanan buku pelajaran dan alat bantu peragaan siswa. 


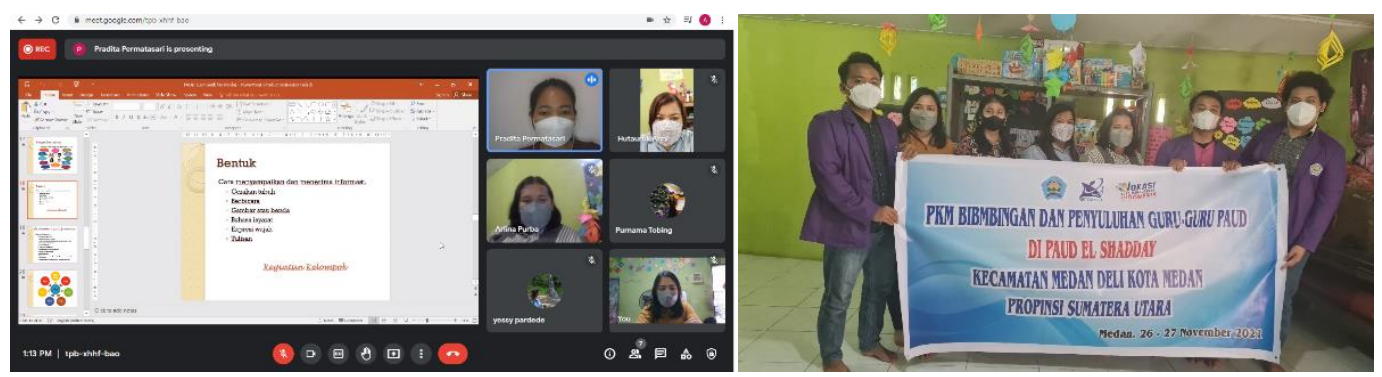

Gambar 1. Pemaparan narasumber secara daring dan pendampingan tim pengabdian serta penyerahan bantuan berupa 1 unit rak besi buku dan 12 unit alat bantu peragaan siswa

Tabel.1 Prosedur Kerja Metode Pelaksanaan

\begin{tabular}{|c|c|c|c|c|}
\hline No & $\begin{array}{l}\text { Prosedur } \\
\text { Kerja }\end{array}$ & Rencana Kegiatan & Partisipasi Mitra & $\begin{array}{c}\text { Kurun Waktu } \\
\text { Realisasi } \\
\text { Program }\end{array}$ \\
\hline 1. & $\begin{array}{l}\text { Pertemuan } \\
\text { awal }\end{array}$ & $\begin{array}{l}\text { Sosialisasi program } \\
\text { kerjasama }\end{array}$ & $\begin{array}{l}\text { Menghadiri } \\
\text { pertemuan awal }\end{array}$ & 90 menit \\
\hline 2. & $\begin{array}{l}\text { Bimbingan } \\
\text { dan } \\
\text { Penyuluhan } \\
\text { Anak }\end{array}$ & $\begin{array}{l}\text { 1. Menjelaskan tentang } \\
\text { perkembangan anak } \\
\text { Paud } \\
\text { 2. Periode penting } \\
\text { tentang } \\
\text { perkembangan } \\
\text { kreativitas dan latihan }\end{array}$ & $\begin{array}{l}\text { Mengikuti pelatihan } \\
\text { selama } 2 \text { hari dari } \\
\text { tanggal } 26-27 \\
\text { November } 2021\end{array}$ & 240 menit \\
\hline 3. & $\begin{array}{l}\text { Meningkatkan } \\
\text { Sarana }\end{array}$ & $\begin{array}{l}\text { Memberikan } 1 \text { buah rak } \\
\text { buku besi }\end{array}$ & Penyediaan tempat & 30 menit \\
\hline 4. & Pelaporan & $\begin{array}{l}\text { Pelaporan seluruh } \\
\text { kegiatan kerjasama }\end{array}$ & Membuat laporan & Satu minggu \\
\hline
\end{tabular}

\section{HASIL DAN PEMBAHASAN}

Hasil dari kegiatan Pengabdian Kepada Masyarakat terhadap guru-guru Paud di El Shadday adalah tercapainya :

a. Guru-guru Paud lebih memahami karakter anak didik

b. Kreativitas guru-guru Paud semakin meningkat melalui permainan edukatif sebagai media bahan ajar untuk meningkatkan sensorik, motorik dan psikomotorik anak didik

c. Guru-guru Paud dapat menggunakan media bahan ajar melalui pemanfaatan bahan yang ada disekitar (misalnya biji-bijian, origami, dll) untuk meningkatkan sensorik, motorik dan psikomotorik anak.

d. Ruangan belajar menjadi lebih luas dan rapi.

Selanjutnya, memberikan 11 (sebelas) buah alat permainan edukatif anak dan 1 (satu) unit rak buku besi. 


\section{KESIMPULAN}

Adapun simpulan dari kegiatan ini adalah:

1. Tujuan pelaksanaan bimbingan dan penyuluhan guru-guru PAUD tercapai.

2. Kegiatan PPM ini menambah 11 (sebelas) buah permainan edukatif anak dan 1 (satu) buah rak buku besi sebagai tempat menyimpan buku pelajaran dan prakarya anak didik.

\section{SARAN}

Saran dari kegiatan ini adalah Pihak mitra menginginkan kelanjutan dari kegiatan ini dan dilakukan Bersama dengan orang tua siswa.

\section{UCAPAN TERIMA KASIH}

Para penulis dengan penuh rasa syukur menyampaikan penghargaan dan mengucapkan terima kasih atas dukungan finansial yang diberikan melalui dana DIPA Politeknik Negeri Medan tahun 2021 dengan nomor kontrak: B/665/PL5/PM.01.01/2021 tertanggal 25 Oktober 2021.

\section{DAFTAR PUSTAKA}

BP-4 Pusat Jakarta. 1994. Majalah Bulanan Nasehat Perkawinan dan Keluarga, Nomor 260/Tahun XXII, Jakarta: BP-4 Pusat Jakarta.

Langeveld, M.J. 1979. Ilmu Jiwa Perkembangan, Bandung: Jemmars.

Monks, F.J. dkk. 1989. Psikologi Perkembangan Pengantar dalam Berbagai Bagiannya, Yogyakarta: Gajdah Mada University Press.

Monks, F.J. dkk. 2002. Psikologi Perkembangan. Yogyakarta: Gadjah Mada University. 